\title{
Preliminary Studies of the Immunomodulator Effect of the Propolis Trigona spp. Extract in a Mouse Model
}

\author{
Nurbani Kalsum ${ }^{1,2, *}$ Ahmad Sulaeman, ${ }^{3, *}$, Budi Setiawan ${ }^{3}$ \\ dan I Wayan Teguh Wibawan ${ }^{4}$ \\ ${ }^{1}$ Postgraduate Program, Bogor Agricultural University, Bogor- 16680, West Java, Indonesia \\ ${ }^{2}$ Agricultural Technology Department, State Polytechnic of Lampung, Soekarno Hatta Street no 1, Bandar \\ Lampung - 35144, Lampung, Indonesia \\ ${ }^{3}$ Community Nutrition Department, Faculty of Human Ecology, Bogor Agricultural University, Kamper Street \\ $2^{\text {nd }}$ Floor $1^{\text {st }}$ Level Wing, ${ }^{4}$ Departement of Animal Disease and Veterinary Public Health, Faculty of Veterinary \\ Medicine, Bogor Agricultural University, Agatis Street $4^{\text {th }}$ Floor $5^{\text {th }}$ Level Wing, Dramaga Campus, Bogor - \\ 16680, West Java, Indonesia
}

\begin{abstract}
Propolis helps boost the immune system naturally because propolis is rich in bioactive compounds and can help increase the production and activity of immune cells. This product has attracted the interest of researchers in recent decades because of the properties of biological and pharmacological, among others such as antimicrobial, antitumor, anti-inflammatory, antioxidant and immunomodulatory. One of bee species that potentially produce propolis in Indonesia is a local bee species Trigona spp. This study aimed to to determine the immunomodulatory effects of ethanol extract of propolis on the Sprague Dawley rats were infected by Staphylococcus aureus. Identification of the phytochemical compounds was undertaken to determine the bioactive compounds contained in propolis liquid. The effects of propolis were analyzed using the macrophage activity as determined by the phagocytic activity and by the production of nitric oxide (NO) in Sprague Dawley rat peritoneal macrophages and the production of antibodies. The results showed that the liquid propolis produces (a) an increase in the phagocytic index, (b) a significant increase in NO production, and (c) an increase over the production of $\operatorname{Ig} G$ antibodies. This study indicates that the ethanolic extract of propolis of Trigona spp. is able to activate macrophages and promote the production of antibodies. The combination of these results suggests that this extract has an immunomodulatory effect and can boost the immune response.
\end{abstract}

Keywords: propolis Trigona spp., macrophages activity, antibodies

\section{Introduction}

Propolis is a resin product that is used by the worker bees to seal cracks, caulking cracks, minimize and close the hole, and the chemical composition depends on the species of bees and vegetation of resin resources [1]. One bee species that potentially produces propolis that Indonesia is a local bee species Trigona spp. More than 300 chemical compounds have been identified from propolis, including polyphenol (eg, flavonoids), coumarin, terpenes, amino acids, minerals, etc. $[2,3,4,5,6]$. This product has attracted the interest of researchers in recent decades because of the properties of biological and pharmacological, among others such as antimicrobial [7, 8, 9], antitumor [10], immunomodulator [11], anti-inflammatory [12], an antioxidant [13].

The immune system or an immune response that occurs as a result of the invasion of bacteria as antigen when it enters the body will be eliminated by neutrophils and macrophages as its role in the innate immune system. Cellular immune response is more effective in eliminating intracellular pathogens. Macrophages are the main effectors in cellular immune response. As a professional phagocytes, macrophages are responsible for destroying cells infected with intracellular pathogens, including Sthapylococcus aureus [14]. Phagocytosis and secretion of reactive oxygen intermediate (ROI) is the main mechanism for destroying macrophage cells infected with intracellular pathogens. Phagocytic activity of macrophages can be enhanced by immunomodulatory substances such as propolis.

In addition, macrophages can also serve as antigen presenting cells (APC). Inside macrophages, the bacteria will be in phagocytosis and then be recognized by the major histocompability complex II (MHC II), and then will be presented in the form of peptide antigen. Furthermore, MHC II binds to T lymphocytes. T lymphocytes are known to have several surface molecules or cluster of differentiation (CD). Antigen peptides that have been presented by MHC II bind to T helper lymphocytes (CD4) on the T-Cell Receptor (TCR) [14]. Macrophages in performing that role, needs help endogenous mediators such as cytokines. While the need for exogenous mediators such as chemical compounds from propolis, still need in-depth research.

Based on the above explanation, the study aims to determine the immunomodulatory effects of ethanol extract of propolis on the Sprague Dawley rats were infected by Staphylococcus aureus. 


\section{Materials And Methods}

\subsection{Plant Material and Extraction of Propolis}

The raw propolis of Trigona spp. bee were obtained from the province of South Sulawesi in Indonesia. The extraction of propolis from a beehive Trigona spp. nest was carried out the Hasan method [15]. A total of 150 grams of honeycomb Trigona spp., macerated with $650 \mathrm{ml}$ of ethanol $70 \%$ (soaked while shaken out by using a shaker) for seven days in a $1000 \mathrm{ml}$ Erlenmeyer flask. After 7 days, the filtrate is decanted and then the residue was macerated again with a $50 \mathrm{ml}$ of $70 \%$ ethanol new. This process is repeated every day for seven days, until solvent ethanol in the residue seemed clear. Thus, the total solvent (ethanol) used was $1000 \mathrm{ml}$, and the total time of maceration for 14 days. The filtrate obtained, united in a dark container. The propolis extracts was diluted with propylene glycol in a ratio of $1: 5(w / w)$.

\subsection{Phytochemical Tests}

Samples were analysed by Pyrolysis Gas Chromatography-Mass Spectrophotometer (Py-GCMS) brand of Type Shimadzu GCMS-QP 2010 to determine the organic compounds contained there in. Extract chemical components were identified by comparing the retention time of the chromatographic peak with WILEY7 database combined with NIST library ver.2.0. Name, molecular weight, molecular formula, and the area under the peak of the components of the test material are determined.

\subsection{Animals}

This study used 25 male rats Sprague Dawley \pm 4 months old with a body weight of $150-200$ grams was obtained from National Agency of Drug and Food of the Republic of Indonesia, Jakarta. The rats kept in a cage measuring $50 \times 30 \times 20 \mathrm{~cm}$, each cage containing two rats. Before being used as experimental animals, all the rats maintained in advance for approximately one week for the adjustment of the environment, controlling health, weight and uniformity of the food and the provision of drinking done on an ad libitum. The ration standard used by AIN-93m [16]. The rats were selected randomly divided into five groups each group consisting of five rats. The first group was given $0.5 \%(\mathrm{v} / \mathrm{w})$ CAPE compound $20 \mathrm{mg} / \mathrm{kg}$ as a positive control [17]. Group II by granting distilled water as a negative control group, the group III, IV, and V was given liquid propolis with a dose of $0,16 \%, 0,46 \%, 1,44 \%$ of body weight/day. The liquid propolis was administered orally for 14 days before infected with Staphylococcus aureus non protein A. Infection with S. aures was conducted on the 15th day by injecting the bacterial inoculum dose of $1 \times 10^{9}$ cfu intraperitoneally. On the 15th day, all rats in each group were sacrificed to be taken peritoneal macrophages and blood, further tests phagocytic activity, NO production and antibodies. The experimental protocols were approved by Ethical Commission of Animal Hospital of Education, Faculty of Veterinary Medicine Bogor Agricultural University has approved the protocol of study (2-2016 RSHP FKH-IPB).

\subsection{Peritoneal Macrophage Preparation}

These five groups of rats were killed by narcotics using chloroform. The rats were placed in the supine position; the skin of the abdomen is opened and cleaned from the sheath peritoneum with alcohol $70 \%(\mathrm{v} / \mathrm{v})$ and injected $\pm 10 \mathrm{ml}$ cold RPMI (Sigma ${ }^{\circledR}$ ) into the peritoneal cavity. Further settling for \pm 3 minutes and rocked slowly (to be attached macrophages in the peritoneal cavity, and around the intestines can be detached and suspended in RPMI medium). Peritoneal fluid removed from the peritoneal cavity by pressing the internal organs with two fingers, then the fluid was aspirated into a syringe (Terumo®) (been part of lean and away from the intestine). Furthermore, the aspirate was centrifuged at $1.200 \mathrm{rpm}, 4^{\circ} \mathrm{C}$ for 10 minutes and then the supernatant was discarded and added with three $\mathrm{ml}$ of "complete RPMI medium" (which contain FBS (Sigma ${ }^{\circledR}$ ) $10 \% \mathrm{v} / \mathrm{v})$.

The number of cells was counted by hemocytometer, then resuspended with complete medium in order to get a cell suspension with a density of $2,5 \times 10^{6} \mathrm{cells} / \mathrm{ml}$. The cell suspension that has been calculated was grown in 90 wells plate $(\mathrm{NucN} 囚)$ which has been given coverslips $(\mathrm{NucN} 囚)$ round, each of the wells containing $200 \mathrm{~mL}\left(5 \times 10^{5}\right.$ cells). Cell was incubated in $5 \% \mathrm{CO}_{2}, 37^{\circ} \mathrm{C}$ incubator (Memmert $\circledast$ ) for 30 minutes, then added to complete medium one $\mathrm{ml} /$ wells and incubation were continued about two hours. Cells were washed twice with RPMI complete medium then added one $\mathrm{ml} /$ wells and incubation was continued for up to 24 hours.

\subsection{Phagocytosis Assay}

The effects of propolis on phagocytic function of macrophages were assessed by Wijayanti [18]. . Peritoneal macrophages that have been cultured the day before, washed twice with RPMI. Latex bead was resuspended so that concentrations of $2.5 \times 107 / \mathrm{ml}$. Latex suspension was added to $200 \mathrm{~mL} /$ wells, incubated for 60 minutes at at $37^{\circ} \mathrm{C}, 5 \% \mathrm{CO}$. The cell was washing three times with PBS to remove particles, which are not phagocytes. Drying at room temperature, fixation with absolute methanol, dried coverslips stained with $20 \%$ Giemsa for 30 minutes. Washing with distilled water, remove it from the culture wells and dry at room 
temperature. After drying, were counted on a glass object. Count the number of latex particles which phagocytes in 100 macrophages, were checked with light microscope 40 - 100x magnification, with a tally $3 x$ replication. Phagocytic activities determined by the number of phagocytic cells are active phagocytosis in 100 phagocytic cells or the number of macrophage cells that are actively engaged in phagocytosis (against the bacterium $S$. aureus) in 100 macrophage cells there.

\subsection{Nitrite Determination}

Nitrite in the presence of macrophage supernatants of treated and untreated rats with propolis was determined as previously described by Dietert et al. [19]. Briefly, macrophages supernatants from treated or untreated propolis were mixed with freshly prepared Gries's reagent $(0.1 \%$ naphthalene diamine hydrochloride, sulfanilamide $1 \%$, and $3 \% \mathrm{H}_{3} \mathrm{PO}_{4}$ ). Absorbance was measured in a microplate reader with $540 \mathrm{~nm}$ filter. The amount of nitrite was determined by a standard curve of $\mathrm{NaNO}_{2}$. Minimal detection for nitrite was $125 \mu \mathrm{M}$.

\subsection{Measurements of IgG}

The contents of IgG in serum were measured by enzyme-linked immunosorbent assay (ELISA), using commercial kits from RayBio® Mouse IgG ELISA Kit Protocol (RayBiotech, Inc).

Statistic's analysis. Data were expressed as mean $\pm \mathrm{SD}$, and significant differences among treatments were determined by analysis of variance (ANOVA) followed by DNMRT test. All statistical analyzes were performed using Microsoft Excel and SAS 9.1. Statistic significances were accepted at $\mathrm{p}<0.05$.

\subsection{Identification of phytochemical compounds in EEP}

\section{Results And Discussion}

Our previous studies have reported the identification components of phytochemical compounds ethanol extracts of Trigona spp. propolis using GC-MS [20]. It has acquired six major compounds identified such as limonene, 1-heptacosanol, heptacosane, 1-hexadecanol, dioctyl adipate, and hexadecane.

\subsection{Effects of EEP on Macrophages Activities}

Effect of propolis Trigona spp. on the phagocytic activity and the ability of macrophage was stimulated by different treatments are shown in Figure 1. Phagocytic index was increased significantly with different concentrations of propolis $(0.16 \%, 0.46 \%$ and $1.44 \%)$ similar to that observed for CAPE $(0.5 \%$ - a positive control). Macrophages are important components of innate immunity. They serve primarily as phagocytic cells and capable of phagocytosis of pathogenic organisms. In addition, macrophages is a potent cytokine producer and plays an important role in various processes, including antigen presentation and wound healing [21]. Orsolic [22] suggests that macrophage activation may occur because of propolis can enhance the activity of the LAF (Lymphosite Activating Factor) that can directly activate macrophages and make it more responsive macrophages to phagocyte microorganisms because propolis has an activity such as IFN- $\gamma$ cytokines which function can activates macrophages.

Table 1. Effect of propolis of Trigona spp on the ability of macrophage phagocytosis

\begin{tabular}{|l|c|}
\hline Groups & Phagocyte Activity (\%) \\
\hline Positive Control (+CAPE) & $87,2 \pm 5,61 \mathrm{a}$ \\
\hline Negative Control & $52,7 \pm 13,19 \mathrm{c}$ \\
\hline Propolis 1 & $80,7 \pm 9,91 \mathrm{~b}$ \\
\hline Propolis 2 & $88,4 \pm 7,62 \mathrm{a}$ \\
\hline Propolis 3 & $90,1 \pm 4,51 \mathrm{a}$ \\
\hline
\end{tabular}

Note :

- $\quad a, b, c, d$ : the same superscripts in the same column are not significantly different $(p>0,05)$

- Macrophages were obtained from the peritoneal cavity of rats and treated with different doses of propolis $(\mathrm{P} 1=0.16 \%, \mathrm{P} 2=0.46 \%$ and $\mathrm{P} 3=1.44 \%)$

- CAPE $0.5 \%$ was used as a positive control. $\mathrm{p}<0.05$, compared Kn (a negative control) (ANOVA, test DNMRT)

The results from this study stated that peritoneal macrophages had been enabled by the adminstration of propolis of Trigona spp., as demonstrated by improving phagocytosis. Strong suspicion of compounds contained in propolis of Trigona spp. such as limonene, able to work activates macrophages. Several other studies have shown that some ingredients in propolis, such as caffeic acid phenethyl ester, cinnamic acid, and artepillin $\mathrm{C}$, is also able to activate macrophages in vitro and in vivo [23]. Literature data indicate that the essential oil of Eucalyptus globulus, which contains p-cymene, which is a member monoterpene, is also capable of inducing macrophage response [24] and p-cymene can also stimulate phagocytosis by binding to the receptor TLR4 [25]. 


\subsection{Effect of EEP on NO Production}

As shown in Figure 2, propolis can increase NO production in macrophages by different treatments. NO production increased significantly with different concentrations of propolis $(0.16 \%, 0.46 \%$ and $1.44 \%)$ similar to that observed in CAPE $(0.5 \%$ - a positive control).

Nitric oxide is a mediator related to cell activation, which contributes to the death or inhibition of a variety of pathogens $[26,27]$. In our study, it was found that $0,16 \%$ of propolis could induce the production. These results are in agreement with other studies that have demonstrated that NO has an important regulatory role in the various types of inflammatory processes. Nitric oxide is synthesized in large quantities by activated macrophages and has been demonstrated to be involved in the pathogenesis of acute and chronic inflammatory conditions [28]. Limonene is reported to suppress the production of TNF- $\alpha$ and NO, thus becoming a potent anti-inflammatory agent, especially in skin inflammatory condition [29]. In vitro studies indicate that Dlimonene increased NO production in peritoneal macrophages obtained from tumor-bearing mice [30].

Table 2. Effect of propolis of Trigona spp against NO production

Note :

\begin{tabular}{|l|c|}
\hline Groups & $\mathrm{NO}(\mu \mathrm{M} / \mathrm{L})$ \\
\hline Positive Control $(+\mathrm{CAPE})$ & $184,164 \pm 0,79 \mathrm{~b}$ \\
\hline Negative Control & $176,790 \pm 5,61 \mathrm{c}$ \\
\hline Propolis 1 & $187,104 \pm 1,14 \mathrm{~b}$ \\
\hline Propolis 2 & $195,866 \pm 0,78 \mathrm{a}$ \\
\hline Propolis 3 & $198,034 \pm 1,15 \mathrm{a}$ \\
\hline
\end{tabular}

- $\quad{ }_{a, b, c, d}$ : the same superscripts in the same column are not significantly different $(p>0,05)$

- Macrophages were obtained from the peritoneal cavity of rats and treated with different doses of propolis $(\mathrm{P} 1=0.16 \%, \mathrm{P} 2=0.46 \%$ and $\mathrm{P} 3=1.44 \%)$

- CAPE 0.5\% was used as a positive control. p <0.05, compared Kn (a negative control) (ANOVA, test DNMRT)

Nitric oxide is a free-radical form of inorganic gas Nitric oxide is a free-radical gas in the form of inorganic and is able to penetrate the membrane layer. NO plays an important role in various physiological functions where one of them is a key mediator in the non-specific immunity. NO can be produced during macrophage activation by antigens such as bacteria, viruses, and parasites. NO toxic to pathogenic bacteria because NO can inhibit the enzyme ribonucleotide reductase and interfere with DNA synthesis. NO also can inactivate enzymes that bind with iron and sulfur, such as Nicotinamide adenine dinucleotide (NADH) and ubiquinone oxidoreductase. Although NO itself is quite toxic and naturally reactive, then NO can easily bind to other molecules such as oxygen and produces nitrates and nitrites that are stable and non-toxic [31].

\subsection{Effect of EEP on Antibody Production}

Effect of different treatment of propolis of Trigona spp. stimulated the production of antibodies by as shown in Figure 3. This propolis extracts increases the potential for the humoral immune response when compared to animals that received antigen without propolis (negative control). Production of IgG antibody increased significantly with different concentrations of propolis $(0.16 \%, 0.46 \%$ and $1.44 \%)$. Treatment of $0.46 \%$ propolis administration was not significantly different from that observed for CAPE $(0.5 \%$ - a positive control). The content of serum IgG was increased dramatically in rats that received $0.46 \%$ propolis of Trigona spp. compared with a provision of another dosage of propolis ( $0.16 \%$ and $1.44 \%)$.

Effect of antigen/foreign objects through the $\mathrm{T}$ cells and $\mathrm{B}$ cells proliferates and differentiates into plasma cells capable of forming and removing Ig (immunoglobulin) with the same specificity as receptors on the cell-surface precursor. Immunoglobulin $G$ is found in blood/serum. Propolis, among others, contains alkaloids, flavonoids, triterpenoids, and saponins. The tendency of increased levels of IgG at a dose of $0.46 \%$ due to the content of the ethanol extracts of propolis of Trigona spp., terpenoids, which is an immunomodulator. As stated by Wagner [32] which generally states that the group of terpenoids, alkaloids or polyphenol have immunomodulatory properties. Administration of terpenoids increased the total antibody production, antibody producing cells in spleen, bone marrow cellularity and alpha-esterase positive cells significantly compared to the normal animals indicating its potentiation effect on the immune system [33].

Table 3. Effect of propolis of Trigona spp against humoral immunity of rats after infected with $S$. aureus

\begin{tabular}{|l|c|}
\hline Groups & IgG (ng/mL) \\
\hline Positive Control (+ CAPE) & $13,459 \pm 0,56 \mathrm{a}$ \\
\hline Negative Control & $8,193 \pm 0,24 \mathrm{~d}$ \\
\hline Propolis 1 & $10,717 \pm 0,80 \mathrm{c}$ \\
\hline Propolis 2 & $13,733 \pm 0,44 \mathrm{a}$ \\
\hline Propolis 3 & $11,853 \pm 0,31 \mathrm{~b}$ \\
\hline
\end{tabular}


Note :

- $\quad \mathrm{a}, \mathrm{b}, \mathrm{c}, \mathrm{d}$ : the same superscripts in the same column are not significantly different $(\mathrm{p}>0,05)$

- Macrophages were obtained from the peritoneal cavity of rats and treated with different doses of propolis $(\mathrm{P} 1=0.16 \%, \mathrm{P} 2=0.46 \%$ and $\mathrm{P} 3=1.44 \%)$

- CAPE $0.5 \%$ was used as a positive control. $\mathrm{p}<0.05$, compared Kn (a negative control) (ANOVA, test DNMRT)

Terpenoid's compounds in propolis extract cause's activation of macrophages followed by differentiation and proliferation. These differentiation and proliferation processes led to an increased number of macrophages circulating through the body [14]. Green propolis Brazil 10\% stimulate the production of antibodies [34]. Giving CAPE (5, 10 and $20 \mathrm{mg} / \mathrm{kg}$ ) in mice BALB/c also increases the production of antibodies [Park et al. in [11]], but in addition to the influence of each element, the synergistic effects of several compounds may be responsible for a variety of pharmacological activities to propolis. Kujumgiev et al. [35] stated that the common biological property of propolis is due to a mix of natural components, and a single element of propolis has greater activity than the total extracts.

The presence of $S$. aureus infections in animals that have activated macrophages causes macrophages to move towards the source of infection. Macrophages that have reached the site of the infection will perform phagocytosis against $S$. aureus. Furthermore, the bacteria are processed within phagolysosome into peptide fragments. Peptide fragments formed by the major histocompatibility complex (MHC) and brought near the cell surface for presentation to $\mathrm{T}$ cells. During phagocytosis and antigen processing, macrophages secrete some secretion; one of them is IL-6.

T-cells helpers through the T-cell receptor (TCR) recognize the antigens S. aureus was presented by macrophages. Ligands between antigen-MHC complex with the TCR-CD3 generate activity in the T-cell membrane inositol into inositol triphosphate and glycerol compound. Inositol triphosphate will increase the calcium ion $(\mathrm{Ca}++)$ in the cytoplasm, whereas diacylglycerol activates the enzyme protein kinase- $\mathrm{C}$. Both are a signal to activate T-cells. T-cell activation can be observed with the secretion of IL-2. IL-2 compounds are useful for the activation of B-cells into plasma cells [11].

Therefore, we consider the possibility that limonene may be one of the most important ingredients in propolis of Trigona spp from Indonesia that plays a role in activating macrophages and increase the production of antibodies.

\section{Conclusion}

This study showed that the ethanol extracts of liquid propolis of Trigona spp. able to activate macrophages and promote the production of antibodies. The combination of these results indicates that the extract has immunomodulatory effects and can boost the immune response.

\section{Acknowledgments}

Thank submitted to the Directorate of Higher Education (Higher Education), which has provided scholarships of Doctoral Program at Bogor Agricultural University. Thanks anyway addressed to the Chief Veterinary Hospital Education Faculty of Veterinary Medicine, Bogor Agricultural University that has been allowed to use the facilities in the cage that agency for the maintenance of experimental animals. Special thanks to Mr. Mahani as a propolis supplier.

\section{References}

[1] Bankova V. Chemical diversity of propolis makes it a valuable source of new biologically active compounds. J Api Prod Api Med Sci. $2009 ; 1: 23-28$

[2] Marcucci MC, Ferreres F, Garcia-Viguera C, Bankova VS, De Castro SL, Dantas AP, et al. Phenolic compounds from Brazilian propolis with pharmacological activities. J Ethnopharmacol. 2001;74:105-112.

[3] Falcão SI, Vale N, Gomes P, Domingues MR, Freire C, Cardoso SM, et al. Phenolic profiling of Portuguese propolis by LC-MS spectrometry: uncommon propolis rich in flavonoid glycosides. Phytochem Anal. 2013;24:309-318.

[4] Shi H, Yang H, Zhang X, Yu LL. Identification and quantification of phytochemical composition and anti-inflammatory and radical scavenging properties of methanolic extracts of Chinese propolis. J Agric Food Chem. 2012;60:12403-12410

[5] Chen CN, Hsiao CJ, Lee SS, Guh JH, Chiang PC, Huang CC et al. Chemical modification and anticancer effect of prenylated flavanones from Taiwanese propolis. Nat Prod Res. 2012;26:116-124

[6] Bonvehí JS and Bermejo FJ. Element content of propolis collected from different areas of South Spain. Environ Monit Assess. 2013;185:6035-6047

[7] Sforcin JM, Fernandes Júnior A, Lopes CAM, Bankova V, Funari SRC. Seasonal effect on Brazilian propolis antibacterial activity. J Ethnopharmacol. 2000;73: 243-249

[8] Freitas SF, Shinohara L, Sforcin JM, Guimarães S. In vitro effects of propolis on Giardia duodenalis trophozoites. Phytomedicine. 2006;13:170-175

[9] Bufalo MC, Figueiredo AS, Sousa JPB, Candeias JMG, Bastos JK, Sforcin JM. Anti-poliovirus activity of Baccharis dracunculifolia and propolis by cell viability determination and real-time PCR. Appl Microbiol. 2009;107:1669-1680 
[10] Bazo AP, Rodrigues MA, Sforcin JM, Camargo JL, Ribeiro LR, Salvadori DM. Protective action of propolis on the rat colon carcinogenesis. Teratog. Carcinog. Mutag. 2002;22:183-194

[11] Sforcin JM. Propolis and the immune system: a review. Journal of Ethnopharmacology. 2007;113:1-14

[12] Silva J C, Rodrigues S, Féas X, Estevinho L M. Antimicrobial activity, phenolic profile and role in the inflammation of propolis. Food and Chemical Toxicology. 2012;50;1790-1795

[13] Kumazawa S, Hamasaka T, Nakayama T. Antioxidant activity of propolis of various geographic origins. Food Chemistry. 2004;84:329-339

[14] Abbas AK, Lichtman AH. Cellular and molecular immunology. $4^{\text {th }}$ ed. WB Saunders Company Saunders, Philadelphia. 2003.pp. $19-347$

[15] Hasan AEZ, Artika IM, Fatoni A. Antibacterial activity of propolis Trigona spp. from Bukittinggi, West Sumatera against Salmonella sp. Chem Progress. 2011;4(2):55-59

[16] Reeves PG, Forrest H, Nielsen, George C, Fahey. AIN-93 purified diets for laboratory rodents: final report of the american institut of nutrition ad hoc writing committee on the reformulation of the AIN-76A rodent diet, committee report. Journal of Nutrition. 1993;123:1939-1951

[17] Park JH, Lee JK, Kim HS, Chung ST, Eom JH, Kim KA, et al. Immunomodulatory effect of caffeic acid phenethyl ester in Balb/c mice. Int. Immunopharmacol. 2004;4(3):429-436

[18] Wijayanti M. Isolasi makrofag dan uji daya fagositosis. 2009. UGM. Yogyakarta

[19] Dietert RR, Hotchkiss JH, Austic RE, Sung Y. Production of reactive nitrogenc intermediates by macrophages. In: Methodes in Immnunotoxicology. editor : Burleson GR, Dean JH, Munson AE. A John Wilye Liss \& sons Inc Publ. New York. 1995;2:99-1117

[20] Kalsum N, Sulaeman A, Setiawan B, Wibawan IWT. Phytochemical profiles of propolis Trigona spp. from three regions in Indonesia using GC-MS. Journal of Biology, Agriculture and Healthcare. 2016;6(14):31-37

[21] Kovacs EJ, Palmer JL, Fortin CF, Fülöp T Jr, Goldstein DR, Linton PJ. Aging and innate immunity in the mouse: impact of intrinsic and extrinsic factors. Trends Immunol 2009; 30:319-324

[22] Orsolic N, Knezevic AH, Basic I. Propolis as a new potential immunomodulator in mice: Antimetastatic Activity of Water Soluble Derivate of Propolis (WSDP), Mellivera. 2002;2(3):39-46.

[23] Gao W, Wu J, Wei J, Pu L, Guo C, Yang J, et al. Brazilian green propolis improves immune function in aged mice. J. Clin. Biochem. Nutr. 2014;55(1):7-10

[24] Serafino, Annalucia, Paola Sinibaldi V, Federica A, Manuela Z, Luana M, et al. Stimulatory effect of Eucalyptus essential oil on innate cell-mediated immune response. BMC Immunology. 2008;9(17). doi:10.1186/1471-2172-9-17

[25] Kummer R, Estevão-Silva CF, Bastos RL, Grespan R, de Souza Silva-Comar FM, Spironello RA, et al. Effect of p-cymene on chemotaxis, phagocytosis and leukocyte behaviors. International Journal of Applied Research in Natural Products. 2015;8(2):20-27

[26] Nathan C, Xie QW. Nitric oxide synthases: roles, tolls, and controls. Cell. 1994;78(6): 915-918

[27] Kourilsky P, Truffa-Bachi P. Cytokine fields and the polarization of the immune response. Trends in Immunology. 2001;22(9): 502-509

[28] Figueroa LA, Navarro LB, Vera MP, Petricevich VL. Preliminary studies of the immunomodulator effect of the Bougainvillea xbuttiana extract in a mouse model. Evidence-Based Complementary and Alternative Medicine. Hindawi Publishing Corporation. 2015, Article ID 479412, 9 pages. http://dx.doi.org/10.1155/2015/479412

[29] Yoon WJ, Lee NH and Hyun CG. Limonene suppresses lipopolysaccharide-induced production of nitric oxide, prostaglandin E and pro-inflammatory cytokines in RAW 264.7 macrophages. J. Oleo Sci. 2010;59:415-421

[30] Del Toro-Arreola S, Flores-Torales E, Torres-Lozano C, Del Toro-Arreola A, Tostado-Pelayo K, Guadalupe Ramirez-Dueñas M, et al. Effect of D-limonene on immune response in BALB/c mice with lymphoma. International Immunopharmacology. 2005;5(5):829-838

[31] Billack B. Macrophage activation: role of toll-like 24. receptors, nitric oxide, and nuclear factor kappa B. Am J Pharmaceutical Edu. 2006;70(5):1-10

[32] Wagner, H. Immunostimulants of fungi and higher plants. Definition Scope Aims Stimulants; 1984. pp.26-32

[33] Raphael TJ, Kuttan G. Immunomodulatory activity of naturally occurring monoterpenes carvone, limonene, and perillic acid. Immunopharmacol Immunotoxicol. 2003;25(2):285-94

[34] Sforcin JM, Orsi RO, Bankova V. Effects of propolis, some isolated compounds and its source plant on antibody production. Journal of Ethnopharmacology. 2005;98:301-305

[35] Kujumgiev A, Tsvetkova I, Serkedjieva Y, Bankova V, Christov R, Popov S. Antibacterial, antifungal and antiviral activity of propolis of different geographic origin. Journal of Ethnopharmacology. 1999;64:235-240 